\title{
Zaydī Theology in Yemen
}

\author{
Hassan Ansari, Sabine Schmidtke, and Jan Thiele
}

\begin{abstract}
This chapter reviews Zaydi theology in Yemen, from the period before and after the unification of the Yemeni and the Caspian imamates to theologians from the ninth/fifteenth century. It traces the foundation of the Zaydī imamate in the northern highlands of Yemen by Imam al-Hādī ilā l-Haqq, and how the Yemeni Zaydīs developed a canon of doctrinal writings of the Imams which remained authoritative over the coming centuries. It considers the role played by Ja'far b. Ahmad b. 'Abd al-Salām al-Buhlūlī in the intellectual development of Yemen's theological landscape, as well as the legacy of al-Hasan b. Muhammad b. al-Hasan al-Rașșās with respect to Bahshamite theology in the country. It also examines the continuity of Bahshamite theology from the seventh/thirteenth century and concludes with a discussion of the emergence of growing opposition among the Zaydīs of Yemen against $\mathrm{Mu}$ 'tazilism in general and the theological views of the Bahshamiyya in particular.
\end{abstract}

\section{Keywords}

Zaydī theology, Yemen, Ja 'far b. Aḥmad b. 'Abd al-Salām al-Buhlūlī, al-Hasan b. Muḥammad b. al-Hasan al-Raș̣̄āṣ, Bahshamite theology, Mu'tazilism, Imam al-Manșūr bi-llāh, Abū l-Husayn al-Bașrī, 'Abd Allāh b. Zayd al-'Ansī

For most of its history, Zaydī theology was heavily influenced by $\mathrm{Mu}^{\text {'tazilite doc- }}$ trines. ${ }^{1}$ Yemen is the only region with a significant Zaydi community until the present day. It is therefore in the country's historical libraries that thousands of $\mathrm{Mu}$ 'tazilite manuscripts have survived. These collections include both texts that were lost in majoritarian Sunni lands as well as many other theological works written by members of the Zaydī community themselves. This chapter provides a survey of theological trends and movements from the beginnings of the Zaydi imamate in Yemen over its political unification with the Caspian Zaydiyya down to theologians from the ninth/fifteenth century. Theologians in Yemen were inclined towards various sub-schools of $\mathrm{Mu}$ 'tazilism from as early as the beginnings of the country's imamate; its impact became even more important when intellectual exchanges with their Caspian co-religionists (a tradition discussed in Chapter 10) increased during the sixth/twelfth century. Yet there was

\footnotetext{
${ }^{1}$ When preparing this chapter, Jan Thiele received funding from the Gerda Henkel Foundation's M4HUMAN programme. Hassan Ansari wishes to thank the Institute for Advanced Study at Princeton, NJ, which hosted him as a member during the preparation of this chapter.
} 
always a lively theological trend that was sceptical about or even completely rejected

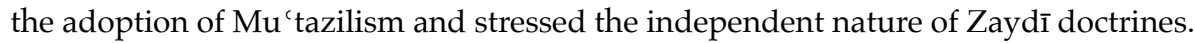

\section{Zaydi Theology before and after the Unification of the Yemeni and the Caspian Imamates}

Since the foundation of the Zaydī imamate in the northern mountainous highlands of Yemen by Imam al-Hādī ilā l-Haqq (d. 298/911), the Zaydīs of Yemen developed a canon of doctrinal writings of the imams which remained authoritative over the coming centuries. First and foremost among these was a collection (majmū $\bar{u}^{c}$ ) of epistles by Imam al-Qāsim b. Ibrāhīm al-Rassī (d. 246/860) which is preserved in numerous collective manuscripts, among them an early copy that may possibly be dated to the fourth/tenth century (Madelung 1965: 96 n. 1). While al-Qāsim advocated in his authentic writings human free will and the absolute otherness of God from His creation

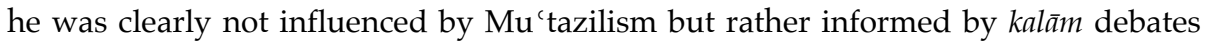
among his Christian contemporaries whom he encountered while residing in EgyptW. Madelung has shown the striking structural resemblances between al-Qāsim and Theodore Abū Qurra (Madelung 1965, 1989, 1991a). ${ }^{2}$ However, later on a number of epistles were ascribed to al-Qāsim which were clearly written at a stage when the Za-

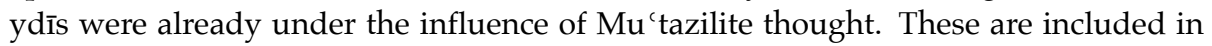
the majority of collective manuscripts of al-Qāsim's epistles that circulated in Yemen. The literary and doctrinal lecagy of al-Qāsim as it was perceived by the Yemeni Zaydīs was therefore somewhat different from the authentic al-Qāsim. ${ }^{3}$ The collection of writings of his son Muhammad (d. 284/897-8) also became part of the canon (Muhammad b. al-Qāsim, Majmūं $)$. As was the case with his father, al-Qāsim, Muhammad's thought shows affinities with cognate $\mathrm{Mu}$ 'tazilite doctrines but he can certainly not be described to have endorsed Mu'tazilite thought. ${ }^{4}$ Al-Qāsim's grandson, Yahyā b. al-Husayn, the later Imam al-Hādī ilā l-ḥaqq (d. 298/911) and founder of the Zaydī imamate in Yemen, is reported to have studied during his sojourn in Northern Iran with Abū l-Qāsim al-Ka 'bī al-Balkhī (d. 319/931) (Jundārī, Tarājim, 41; Zaryāb 1994:

\footnotetext{
${ }^{2}$ As a result, al-Qāsim's doctrinal views differed from those of the prominent representatives of the early Kūfan Zaydiyya, esp. Aḥmad b. 'Īsā b. Zayd (d. 247/861), his companion Muhammad b. Manșūr alMurādī (alive in 252/866), and the latter's younger contemporary al-Hasan b. Yahyā b. al-Husayn b. Zayd; for example, the earlier Zaydīs were proponents of divine determinism. See Madelung 1965: 80-5; Madelung 1989; Ansari 2011.

${ }^{3}$ W. Madelung has distinguished in detail the authentic from the unauthentic works of al-Qāsim (Madelung 1965: 97ff.). B. Abrahamov, by contrast, considers most of the works that were classified by Madelung as inauthentic as authentic and concludes that the latter endorsed at a later stage of his life $\mathrm{Mu}^{\text {c }}$ tazilite thinking (Abrahamov 1987, 1990, 1996). For a critical discussion of his conclusions see Madelung 1989; 1991b - at some stage the Zaydīs of Yemen, following the Kufan tradition, also added a collection allegedly containing the doctrinal writings of Imam Zayd b. 'Alī b. al-Husayn (b. 75/694-5; d. 122/740) (Zayd b. 'Alī, Majmū'). These are evidently not authentic and rather originate partly with the early Kūfan Zaydiyya and partly with the Yemeni Zaydiyya who claimed that Zayd b. 'Alī's theological thought agreed with the views of the Mu'tazila (Madelung 2002).

${ }^{4} \mathrm{~A}$ thorough investigation of his writings, as well as the writings of the Zaydi Imams of Yemen of the fourth/tenth to sixth/twelfth century, is still a major desideratum. Moreover, the authenticity of the writings included in the respective majām $\bar{\imath}^{`}$ collections still needs to be established.
} 
151) - if true, he was in fact the first Zaydī Imam to study with a representative of the $\mathrm{Mu}$ 'tazila. As a result, his doctrinal thought was deeply influenced by the theological views of the Mu'tazilite school of Baghdad, although al-Hādĩ refrained from expressly stating his agreement with their doctrines or even identifying himself with the Mu'tazila (Madelung 1965: 164-7; 'Abd al-Rahmmān 2003a). His literary legacy was likewise transmitted among the Zaydīs of Yemen in a popular $m a j m \bar{u}^{`}$ of epistles (al-Hādī ilā l-ḥaqq, Majmū 'a fākhira; Majmū'). Among the Yemeni Zaydīs of later centuries, the teachings of al-Hādī and his grandfather al-Qāsim were largely identified with each other. Canonical status was also accorded to the writings of al-Hādì's sons Muhammad al-Murtaḍā li-Dīn Allāh (d. 310/922) (al-Murtaḍā li-Dīn Allāh, Majmū c) and Imam Aḥmad al-Nāṣir li-Dīn Allāh (301/913-322/934) (Madelung 1965: 169-74, 191-3; Madelung 1985; 1990).

With Imam al-Manșūr bi-llāh al-Qāsim b. 'Alī b. 'Abd Allāh al-'Iyānī (b. between 310/922 and 340/951, d. 393/1003) (Madelung 1965: 194-8; al-Wajīh 1999: 773-5 no. 833), a great-grandson of al-Qāsim b. Ibrāhīm's son Muhammad, the doctrinal development of the Zaydiyya entered a new phase. Unlike earlier Imams, al-Qāsim al- 'Iyānī addresses in his writings philosophical notions and issues belonging to the so-called subtleties of kalām (al-Qāsim al-'Iyānī, Majmī' '), and the same applies to his son, alMahdī li-Dīn Allāh al-Husayn (d. 404/1013), who wrote a book on the nature of beings, Kitāb al-Ṭabā' '` (al-Husayn b. al-Qāsim al- 'Iyānī, Majmū '; on him, see Madelung 1965: 198-200; al-Wajīh 1999: 384-8 no. 385). Other than this, both Imams remained by and large faithful to the doctrines of al-Hādi ilā l-haqq. The works of both Imams were referred to by the adherents of a theological doctrine that evolved among the Zaydīs of Yemen during the fifth/eleventh century who otherwise took the teachings of the early Imams as their starting point. ${ }^{5}$

A major role in formulating and systematizing this new tradition was played by Muțarrif b. Shihāb b. 'Āmir b. 'Abbād al-Shihābī (d. after 459/1067). It was after him that this strand was retrospectively labelled as the 'Muțarrifiyya'. Muțarrif b. Shihāb also founded the first hijra ('abode of emigration'), in the village of Sanā', south of Șan ' $\overline{\mathbf{a}}^{\prime}$ (Madelung 1991a). Hijras were a characteristic institution of the Muțarrifī community that considerably helped them to spread and establish their teaching over wide parts of the country. While the adherents of this doctrine claimed to cling fervently to the theological teachings of al-Hādī and the latter's sons Muhammad and Ahmad, they actually developed a cosmology and natural philosophy of their own. Most renowned among their doctrines was their view that God had created the world out of three or four elements, viz. water, air, winds, and fire. Changes in the world result, as they claim, from the interaction of these constituents of the physical world-in other words from a natural causality—rather than God's directly acting upon it (Madelung 1965:

\footnotetext{
${ }^{5}$ Again, the authenticity of the various epistles still needs to be verified in detail. Since none of their writings has been studied in any detail, it cannot be ruled out at present that some epistles were later on ascribed to one of the Imams by later adherents of the Muțarrifiyya. After al-Husayn was killed in Șafar 404/September 1013, his followers believed in his imminent return as the Mahdi - the adherents of this belief later became known as the Husayniyya. As a result, his successors refrained from using the title of Imam for themselves but rather called themselves amīrs—viz. his oldest brother Ja 'far b. al-Qāsim al- 'Iyānī (d. 450/1059) as well as his sons al-Sharīf al-Fāụil al-Qāsim (d. 468/1075) and Dhū l-Sharafayn Muhammad (d. 477/1084) (al-Raba' 'í, Sìra; Madelung 1977). The followers of the Husayniyya also developed their own peculiar doctrinal views which were later criticized by the Zaydīs. Cf., for example, al-Raba 'î̀, Sìra, 345-65.
} 
202f.; 1975; 1991a; Ansari 2006).

During the reign of Imam Abū Țālib al-akh̄̄r Yahyā b. Aḥmad b. al-Husayn b. alMu'ayyad bi-llāh Aḥmad b. al-Husayn al-Hārūnī (d. 520/1126) (al-Wajīh 1999: 1088f. no. 1163) the Yemeni and the Caspian Zaydiss were eventually unified for the first time in history under a common political and religious leadership. After many years of quasi-isolation, the change of the politico-religious framework exposed the Yemeni Zaydīs to new theological influences. In order to strengthen the authority of the Imam in both communities, the intellectual gap between them was supposed to be bridged by a harmonization of their respective scholarly traditions. Unlike their Yemeni coreligionists, the Zaydīs of Rayy and Northern Iran had embraced Bahshamite theology as early as the fourth/tenth century (see Chapter 10). The Bahshamiyya was a branch of Basran Mu'tazilism named after Abū Hāshim al-Jubbā'̄̄̄ (d. 321/933), a towering figure of Muslim theology, who had, in many respects, redefined the doctrinal foundations of the school. Bahshamite theology experienced a flowering in Rayy and in the Caspian region under the reign of the Būyids, who made the city of Rayy the centre of the Bahshamiyya's chief theologians. This also affected the Zaydīs intelligence in the region: many scholars were attracted by the study circles of such eminent thinkers as 'Abd al-Jabbār al-Hamadānī (d. 415/1025) or al-Hasan b. Aḥmad Ibn Mattawayh.

Some information about the doctrinal developments among their Iranian coreligionists may have reached Yemen as early as during the time of the Imam al-Nāșir li-Dīn Allāh Abū l-Fatḥ al-Nāṣir b. al-Husayn al-Daylamī, who hailed from the Caspian region and arrived in al-Bawn in Yemen in 430/1039, that is one year after claiming the Zaydī imamate in 429/1038 (Madelung 1965: 203, 205; Madelung 1980; Mohaqqeq 2008). Abū l-Fath engaged in combats with the local descendants of al-Hādī and with Ja'far b. al-Qāsim al- 'Iyān̄i, the leader of the Husayniyya. He also waged war on the Ismā' îlī al-Ṣulayḥ̄ who killed Abū l-Fath in 444/1052-3. Reportedly, Abū 1-Fath wrote a refutation of the local Zaydī doctrines, al-Risāla al-mubhija fì l-radd 'alā l-firqa al-dālla al-mutalajlija $\left(\right.$ lost $\left.^{6}\right)$ which may have been the first refutation of what was later to be called 'Mutarrifiyya', suggesting that it was already at this time that the political conflict had doctrinal dimensions as well.

The attempts to introduce the Caspian intellectual tradition into Yemen and to establish it among local scholars gradually increased under Imam al-Mutawakkil 'alā llāh Aḥmad b. Sulaymān (r. 532-66/1137-70) (for his biography, see al-Thaqafī, Sìra). During his reign, the dissemination of Bahshamite kalām by travelling scholars significantly grew and Yemeni students in theology undertook extended visits to the Caspian region. Al-Mutawakkil himself studied with several of these scholars, the most illustrious theologian of whom was Zayd b. al-Hasan b. 'Alī al-Bayhaqi

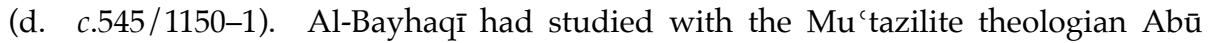
Sa'd al-Muhassin b. Muhammad b. Kirāma (or: Karrāma) al-Bayhaqī al-Barawqan̄̄ ('al-Hākim al-Jishumī', d. 494/1101; on him, see Chapter 9, Section III) and might consequently have contributed to the transmission of al-Jishumī's writings and their high popularity in Yemen. During his first years in Yemen, al-Bayhaqi taught at the heavily symbolic al-Hādī Mosque in Șa'da, which houses the tombs of the

\footnotetext{
${ }^{6}$ According to Mohaqqeq 2008: 758, a manuscript of the tract is preserved in a manuscript of the State Library Berlin, 'Ahlwardt, no. 4950'. This information, which is wrong, is based on a misunderstanding of Ahlwardt 1887-99: iv. 331.
} 
founder of the Yemeni imamate and of several of his successors. He then relocated his teaching activities southwards and settled in the Muțarrifiyya's oldest hijra Sanā choice that was certainly well considered (Madelung 1965: 210-12; Schwarb 2011: 268-70). Al-Bayhaqī succeeded to convince a number of students of the superiority of Bahshamite doctrines over Muțarrifĩ theology. Credibility for the imported doctrinal notions was provided by the authority they received through the Imams of Northern Iran, the Buṭhān̄i brothers al-Mu'ayyad bi-llāh Aḥmad b. al-Husayn al-Hārūn̄i (d. 411/1020) and al-Nāțiq bi-l-Haqq Abū Țālib Yahyā b. al-Husayn (d. 424/1033) who both espoused Bahshamite kalām and whose writings became available in Yemen during this period. This development ushered in an unprecedented 'mu 'tazilization'

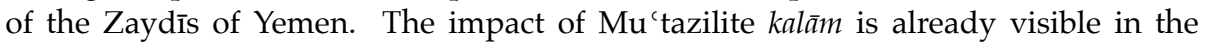
doctrinal works of Imām al-Mutawakkil 'alā llāh, e.g. in his comprehensive Haqā'iq al-ma'rifa fí 'ilm al-kalām (al-Mutawakkil 'alā llāh, Haqā'iq). In its structure, the book resembles the majām $\bar{\imath}^{`}$ of the earlier Imams; yet in doctrine, al-Mutawakkil endorses

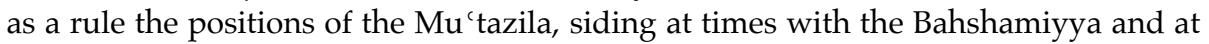
times with the School of Baghdad (Ansari 2011: 195-211; for similar observations for his works on legal theory, see Ansari and Schmidtke 2013a: 101 n. 37).

Among al-Bayhaqī's successors was Ja'far b. Ahmad b. 'Abd al-Salām al-Buhlūlī (d. 573/1177-8), who should play an important role in the future intellectual development of Yemen's theological landscape. Ja'far b. Ahmad came from an influential Ismā 'îlī family of judges. Before he attended al-Bayhaqī's lectures, he had followed Mutarrifī teachings. The fact that he eventually migrated to the opposing camp and approved al-Mutawakkil's imamate was officially acknowledged: in 545/1150-1 he was appointed judge ( $q \bar{a} d \bar{l})$ of $\operatorname{Ṣan}^{\prime} \overline{\mathbf{a}}^{\prime}$, and still in the same year he was selected to accompany his teacher on his travels in order to seek further instruction outside Yemen. Shortly after their departure, al-Bayhaqī died still on Yemeni soil, and so Ja'far b. Ahmad continued his travel alone. He spent about eight years at several centres of learning in Iraq and Northern Iran. When he eventually sojourned in Rayy, he studied with Aḥmad b. Abī l-Hasan al-Kanī (d. c. 570/1165-6), al-Bayhaqī's former student, and he is known to have likewise been taught by Muhammad b. Aḥmad al-Farrazādhī, one of the members of the renowned Farrazādhī family in this town. Ja'far b. Ahmad also spent some time in Kufa and in Mecca, where he studied with the eminent Zaydi scholar Abū l-Hasan 'Ulayy b. 'Īsā b. Hamza b. Wahhās al-Sulaymānī (d. 556/1161-2) (on him, see Lane 2006: 26-9, 48-53, 251).

Upon his return to Yemen, Ja'far b. Ahmad brought along many Mu'tazilite works-many of which were later on copied for the library of Imam al-Manșūr bi-llāh 'Abd Allāh b. Hamza (on him see Section II)—and he settled again in Hijrat Sanā' and established his madrasa next to the village's Muțarrifī madrasa. His teachings laid the basis for the emergence of a new generation of scholars. This new theological movement was given the label of 'al-mukhtari' $a$ '. The description was derived from the notion of $i k h t i r \bar{a} \bar{c}^{c}$, a term that refers to the idea that God spontaneously creates accidents ( $a^{\prime} r \bar{a} d$, sing. 'arad). Following the Bahshamite theory, Ja'far b. Ahmad and his followers believed accidents to be the grounds of such changing qualities of bodies as motion and rest, colours, or their annihilation. For them, God's omnipotence necessarily implies that $\mathrm{He}$ is able to create ex nihilo such accidents. This position consequently contradicted the Muțarrifī doctrine that events and changes in the 
created world are the result of a natural causality inherent to bodies.

In public disputations and in his writings Ja ' far $\mathrm{b}$. Ahmad not only attacked his Muțarrifī detractors but also the Sunnis of Yemen. A number of polemical tracts from his pen have survived in manuscript form. In addition, he was the author of a doctrinal summa, titled Kitāb Mishkāt al-mișbāh wa-hayāt al-arwāḥ (Sobieroj 2007: 285f. no. 133) and of some shorter theological manuals, in which he embraces Bahshamite doctrines. However, his subscription of their teaching explicitly excluded their theory of imamate. Ja 'far therefore wrote a refutation of Ibn Mattawayh's chapter on the imamate contained in al-Majmū' fíl-Muhīt bi-l-taklīf. Ja'far b. Ahmad survived Imam al-Mutawakkil and still experienced the beginning of the vacancy of the Zaydī imamate-a period that lasted about twenty-seven years. Ja 'far died in 573/1177-8 and was buried in Hijrat Sanā' (Madelung 1965: 212-16; Zayd 1997; al-Wajīh 1999: 278-82 no. 257; Schwarb 2011: 270-3).

It was one of Ja'far b. Aḥmad's students, al-Hasan b. Muhammad b. al-Hasan al-Rașșās (b. 546/1152, d. 584/1188), who then gave a lasting intellectual impetus to the Yemeni appropriation of Bahshamite theology. Still during his teacher's lifetime, al-Rașạās started writing his first works on theology and legal theory. Following his teacher's death, he succeeded Qāḍi Ja 'far as the new head of the school and continued the latter's teaching activities in Hijrat Sanāc ${ }^{c}$. Al-Rașṣās further wrote extensively on theological topics, putting much emphasis on the so-called subtle questions (daq $\bar{a}^{\prime} i q$ or laț $\bar{a}^{\prime}$ if). He also was most probably motivated by his desire to disprove the teachings of the Muțarrifiyya. Although al-Rașșāṣ rarely mentions his detractors and their doctrines explicitly, this scenario is quite likely: it was precisely the subtle questions related to natural philosophy over which both schools were deeply divided. The deeper reason behind their fierce opposition was that the conceptual construct of God and His relation to the created world was built upon these very questions. Therefore, the denial of such fundamental assumption pulled the rug out from under the whole theological system. It is therefore not surprising that both schools quarrelled so harshly about rather detailed issues whilst agreeing at the same time on such central principles as that of free will or the denial of anthropomorphism.

Al-Rașsāṣs's doctrines in theology and natural philosophy fully stand in the tradition of Bahshamite teaching and, at the same time, set some new tones. With regard to the basic concepts of ontology, his ideas and thoughts about 'things' or 'entities' (ashy $\bar{a}$ ', dhaw $\bar{a} t)$ follow the axioms of earlier representatives of the school. He adopts their definition of 'things' as that which can become objects of knowledge and of predication. The generic term of 'things' encompasses God, atoms (jawāhir)—i.e. indivisible particles of which created bodies are made up-and accidents ( $\left.a^{\prime} r \bar{a} \bar{d}\right)$. In this context, it is of some historical importance that al-Rașșās refuted a passage from Rukn al-Dīn Maḥmūd Ibn al-Malāḥimī's (d. 536/1141) Tuhfat al-mutakallimīn fì l-radd 'alā l-falāsifa. In his treatise, al-Rașșās argues against Ibn al-Malāḥimī that predications about the very nature of things (such as 'the atom is an atom') are not identical with describing them as existing. Al-Rașșāṣ's defence of the classical Bahshamite distinction between existence and that which things are in themselves is one of the oldest testimonies to the Yemenite reception of the school founded by Abū l-Husayn al-Bașrī (d. 436/1044) (Ansari 2007).

Al-Rașșās does not add anything substantial to the Bahshamite theories of atoms 
and accidents. These topics had already been comprehensively covered in fundamental works by theologians of the fifth/eleventh century. Among these works are alHasan b. Aḥmad Ibn Mattawayh's extensive Kitāb al-Tadhkira fī aḥkām al-jawāhir wa-l$a^{\prime}$ răd. Al-Rașșāṣ was familiar with this text and used it as a reference in several of his works.

Later generations of Zaydī theologians attached great importance to al-Rașșāș's treatise on 'effectors' (Kitāb al-Mu'aththirāt) (Thiele 2011). This concise text has survived in an important number of manuscripts, dating up to the middle of the eleventh/seventeenth century. Al-Rașṣās wrote this work in an attempt to formulate a comprehensive theory of causation. He possibly relied on al-Hākim al-Jishumī's earlier, in some respects inconsistent thoughts about this matter (Ansari 2011: 313-28; Thiele 2012). In the framework of Bahshamite teaching, al-Rașșāṣ develops a taxonomy of what is labelled 'effectors' (mu 'aththirāt) and 'analogous phenomena' (mā yajrī majrā l-mu'aththir). He furthermore seeks to theoretically explain why some of these 'effectors' are necessarily and others contingently effective.

Another work, entitled Kayfiyyat kashf al-ahkēm wa-l-șifāt 'an khașā'iș al-muqtadiyāt $w a-l-m u$ 'aththirāt, offers rare insight into the historical development of the Bahshamite teaching on attributes. In this text, al-Rașșās elaborates his approach to the so-called 'theory of states', that is the theory introduced by Abū Hāshim al-Jubbā' '̄ (see Chapter 22). In addition to exploring the șifāt, i.e. that which is usually translated from the Arabic as 'attributes', al-Rașșās opens his analysis to broader considerations on the concept of ahkām-a term which might be rendered as 'characteristics', but actually denotes an ontological category distinct from the 'attributes'. Earlier Bahshamite theologians already made a conceptual distinction between șifa and hukm. However, their understanding of the latter remains, to some extent, vague. It was only with Abū

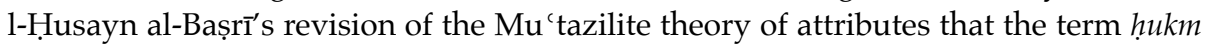
was eventually used in a more formal sense (Schmidtke 1991: 174-7). It seems that al-Rașșāṣ's usage of the term was shaped from this angle, since he adopts a definition of hukm that is only known from the writings of Ibn al-Malāhimī. According to this understanding, the distinction between sifät (or aḥwāl which is used as a synonym) and $a h k \bar{a} m$ is an epistemological one: in order to gain knowledge about things, we have to consider two objects qualified by the same hukm, whereas a șifa can only specify one object.

The Kayfiyya is divided into chapters devoted to four categories of șifāt and three categories of $a h k \bar{a} m$. This classification is made in an introductory chapter according to the manner or modality (kayfiyya) by which properties of things become actual (thabata). As is expressed in the title of the book, one of the author's main interests consists in the question what each category of properties reveals about the very nature of its object of qualification. This particular approach can be seen as a corollary of the Bahshamite theory that things are known by virtue of their properties. The purpose of al-Rașșāș's raising this question consequently derived from a central theological problem: if we describe God and His creatures by univocal properties, how then can His absolute transcendence be preserved (Thiele 2013a: 131-200)?

Al-Rașșāṣ wrote a number of additional works on lațîf al-kalām that have as yet not been found in manuscript form and appear to be lost. Only some self-quotations provide selective insight into their content and reveal that he discussed the nature of 
attributes, accidents, and of 'things' (dhawāt) in general (Thiele 2010: 549; Thiele 2013a: 37-9).

Prompted by their opponents' focus on doctrinal issues, the Muțarrifīs in turn countered the attack: they claimed that they were faithful followers of the teachings of the early Imams and argued that it was in fact the adoption of Basran $\mathrm{Mu}^{\text {'tazilism that }}$ constitutes a deviation from the truth and as such an illegitimate innovation. Moreover, with the new arrival of $\mathrm{Mu}$ 'tazilite works, the Muțarrifīs apparently used increasingly the doctrines of the Baghdādī Mu'tazilites to refine their own kalām in their intellectual conflict against their opponents. These could be gleaned from the Maqāalat of Abū l-Qāsim al-Balkhī al-Ka 'bī (d. 319/931) as well as the K. al-Masā̄il fì l-khilāf bayn al-Bașriyyīn wa-l-Baghdādiyyīn of Abū Rashīd al-Nīsābūrī, a systematic comparison between the doctrines of the adherents of the two $\mathrm{Mu}^{\prime}$ tazilite schools (Ansari and Schmidtke 2010). The influence of the Baghdādī doctrines among the representatives of the Mutarrifiyya during this period is evident, for example, in the K. al-Burhān al-rā'iq by the Muțarrifī theologian Sulaymān b. Muhammad b. Aḥmad al-Muhallī who flourished during the second half of the sixth/twelfth century (Madelung 1975). As such the conflict took on the dynamics of the old opposition between the Baghdādīs and the Basrans. However, whereas the conflict between the two $\mathrm{Mu}$ 'tazilite systems remained a purely theological one, the confrontation between the different Zaydi groups of Yemen eventually led to an open war between the two. There are some indications that the Muțarrifī theologians also made use of the doctrines of Abū 1-Husayn al-Bașrī and his followers who in many ways had departed from the theology of the Bahshamites. The few Mutarrifī theological texts that were written during the sixth/twelfth century testify to the development of the Muțarrifī doctrine at the time ('Abd al- ' $\bar{A} t \underline{1}$ 2002; Ansari 2001).

\section{The Continuity of Bahshamite Theology from the Sev- enth/Thirteenth Century Onwards}

When al-Rașșās died in 584/1188 the religious and political leadership of the Zaydī community was still vacant. It was only in 593/1197 that al-Rașșāș's former student 'Abd Allāh b. Hamza (d. 614/1217) rose as Imam al-Manșūr bi-llāh. It was under his reign that the Bahshamite strand irrevocably overcame its ideological detractors: the Imam, who himself left a number of important theological works, led a merciless war against the Muțarrifiyya. Their persecution and the destruction of their hijras under his reign eventually led to the extinction of the sect. ${ }^{7}$ Numerous of 'Abd Allāh b. Hamza's doctrinal writings are refutations of the Mutarrifiyya (as well as justifications of the Imam's merciless persecution of their followers for which he faced severe criticism). Other than that he composed Sharh al-Risāla al-nāṣiha bi-l-adilla al-wādiha, a detailed theological compendium (with particular focus on the concept of the imamate) in which

\footnotetext{
${ }^{7}$ The principal historical source for al-Manșūr's fight against the Muțarrifiyya is the sīra of the Imam by his chief secretary Abū Firas b. Di'tham. Vols. ii and iii have been published as Ibn Di'tham, Sìra. Another copy of vol. ii that was not consulted by the editor is preserved as MS Vatican ar. 1061; cf. Levi Della Vida 1935: i. 131. H. Ansari has identified copies of vols. i and iv of the sir $r$ that previously had been presumed lost; see Ansari 2013.
} 
he endorses Bahshamite theological notions. In its overall structure, however, the book resembles that of the writings of the earlier Imams rather than theological summae by professional theologians (e.g. by his teacher al-Rașșāṣ) and it is replete with quotations from the writings of the Zaydī Imams, a characteristic that also ensured the work's lasting popularity among the Zaydī community. Al-Manșūr's Kitāb al-Shāfì is a refutation directed against the Ash 'arites of Yemen, focusing specifically on the notion of the imamate. Moreover, it is noteworthy that al-Manșūr is one of the first Zaydī authors of Yemen to cite Sunnī traditions supporting the cause of 'Alī b. Abī Țālib and the ahl al-bayt in his battle against the Shāfi 'īs in Yemen who were polemicizing against Shī 'ism (Ansari and Schmidtke 2013a; Ansari and Schmidtke 2013b). Doctrinal issues are also discussed in his al- 'Iqd al-thamīn, a book that is directed against the Imāmiyya (Jarrar 2012), as well as in his numerous responsa (see al-Wajīh 1999: 578-86, no. 592; al-Manșūr bi-llāh, Majmū'c).

At the turn and during the first decades of the seventh/thirteenth century, a number of other theologians who had studied with al-Rașsaas gained some scholarly prominence. Among them was Muhȳī l-Dīn Muhammad b. Aḥmad b. al-Walīd al-Qurashī al-Anf (d. 623/1226), author of al-Jawāb al-hāsim bi-hall shubah al-Mughnī, a critical response to 'Abd al-Jabbār al-Hamadānī's account of the imamate in his voluminous Kitāb al-Mughn̄ fĩ abwāb al-tawhīd wa-l-' adl. Apart from being a scholar in his own right, Muhammad Ibn al-Walīd also belonged to the staff of professional scribes who were instrumental in the establishment of al-Manșūr bi-llāh's library in his residential town Zafār. The foundation of this library can be regarded as the culmination of the endeavour to transmit as many books as possible from Northern Iran to Yemen. Many of the texts copied for al-Manșūr bi-llāh's library have survived as unique manuscripts (Ansari and Schmidtke 2010).

Another of al-Rașșāṣ's students, Sulaymān b. 'Abd Allāh al-Khurāshī (d. after 610/1214), wrote a commentary on his teacher's al-Tahṣīl fì l-tawhīd wa-l-ta 'dīl, a short theological compendium. The third volume of this commentary has been preserved in manuscript form and shows al-Khurāshī's remarkably close familiarity with the works of Ibn al-Malāhimimī (al-Khurāshī, Taḥṣ̂̄l; Ansari and Thiele 2015). Al-Khurāshī's text is only the first in the chronology of several commentaries on the Kitāb al-Tahṣīl that were written within a period of thirty years after al-Rașșāș's death. Consequently, it appears that the Kitāb al-Taḥșil was a popular work among this generation of theologians. The commentaries on al-Rașșāṣ's theological manual include one in several volumes by Husayn b. Musallam al-Tihāmī, who studied with al-Rașșāṣ's own student Abū l-Qāsim b. Shabīb al-Tihāmī. Husayn b. Musallam al-Tihāmī's text appears to be partially preserved and is related in its structure and content to the third and shortest commentary on the Kitāb al-Tahṣ̂̄l by al-Rașṣāṣ' son Shams al-Dīn Aḥmad b. al-Hasan al-Rașạāṣ (d. 621/1224) (Thiele in press).

Aḥmad al-Rașṣāṣ's historically most influential work was a brief introduction to the fundamentals of Bahshamite doctrines. This text, entitled Mișbāh al-'ulūm fì ma'rifat al-hayy al-qayyūm (also known as al-Thaläthūn mas'ala), was widely read among the Zaydīs of Yemen and still serves as a textbook in contemporary circles of religious learning. In addition, Mișbāh al-' ulūm was subject to several commentaries, one of them being al-Ị̇āh li-fawā'id al-Miṣbāh by his student Humayd b. Ahmad al-Muhallī al-shahīd (killed in 652/1254) (Ansari and Schmidtke 2011: 196 no. 50). Humayd al- 
Muhallī had studied with 'Abd Allāh b. Hạza, Ibn al-Walīd and Zayd b. Aḥmad al-Bayhaqi, who coming from Iran arrived in Yemen in 610/1213-14, and he is primarily known as the author of the biographical work al-Hadā'iq al-wardiyya. That he was also a well-versed theologian is shown by his comprehensive works on kalām, viz. his 'Uyūn al-mustarshidīn fì ușül al-dīn, a theological summa in four parts in which the author comments upon a credal work by al-Manșūr bi-llāh (al-Wajīh 1999: 408), and his al-Kawākib al-durriyya fì taf̣̦il al-nafahāt al-miskiyya (Ansari and Schmidtke 2011: 197f. no. 60). The latter work is not a conventional summa but rather encompasses all major aspect of the subtleties of theology. The first part of the work discusses logical and epistemological questions. The second and longest chapter then deals with the definition of 'things' or 'entities' (dhawāt), followed by a comprehensive exposition of the basic constituents of the world, namely atoms (jawāhir) and accidents ( $\left.a^{\prime} r \bar{a} \bar{d}\right)$. The last part finally addresses the topic of 'attributes' (șifät) and 'characteristics' (ahkām). Humayd's work highlights how centrally theologians of this time were concerned with the field of lațīf al-kalām.

Humayd al-Muhallī resided in Mislit, located in Banū Qays, where he taught along with other prominent scholars of his time. The village's madrasa had built up a considerable reputation as a centre of learning, and so the later Imam al-Mahdī li-Dīn Allāh Abū Țayr Aḥmad b. al-Husayn b. Ahmad b. al-Qāsim (d. 656/1285) studied there theology and legal theory, as is reported in his biography (sĩ $r$ ) which contains a detailed chapter on his formation (Ansari and Schmidtke 2011). A further centre of theological teaching was the madrasa al-manșūriyya in Hūth, Ahmad's next station. Although the detailed report about Ahmad's studies are only a snapshot of the Zaydīs' educational culture during the first half of the seventh / thirteenth century, they allow us to catch a glimpse of the time's intellectual milieu and the texts that were considered as fundamental in the scholarly instruction in the science of kalām. Alongside the writings by such leading (Sunnī-Mu 'tazilite) authorities as Abū Rashīd al-Nīsābūrī, Ibn Mattawayh, or Ibn al-Malāhimī, many Yemeni-Bahshamite authors are prominently represented in the curriculum: the textbooks include several writings by al-Hasan al-Rașșās, Husayn b. Musallam al-Tihāmī's commentary on al-Rașșașs al-Tahṣil or Humayd al-Muhallî’s alKawākib al-durriyya (Ansari and Schmidtke 2011). Another influential theologian during this period was al-Husayn b. Badr al-Dīn Muhammad (d. 662/1263-4), author of Yanābi ' al-nașīha fi ușūl al-dīn, a theological summa with Bahshamite tendencies which again resembles in structure and its reliance on the Qur'ān and hadith the doctrinal works of al-Manșūr bi-llāh. Al-Husayn also wrote a concise credal work, titled al-'Iqd al-thamīn fì ma'rifat rabb al- 'ālamīn, which enjoyed immense popularity over the centuries. From his pen we also have numerous refutations directed against the Muțarrifiyya (al-Wajīh 1999: 390-3 no. 388). Similar tendencies can be found in Qawā'id 'aqā' id Āl Muhammad by Muhammad b. al-Ḥasan al-Daylamī (d. 711/1311-12) who wrote about the same time.

Over the course of several centuries, we can identify several important scholarly families that brought forth a number of prominent theologians: alongside the descendants of al-Hasan al-Rașșāș, a number of members of Humayd al-Muhallī's family were reputed theologians and authors. One of them was the shahīd's grandson al-Qāsim b. Ahmad al-Muhallī, who lived in the first half of the eighth / fourteenth century. The dictation of his critical remarks on, and corrections to, al-Hasan al-Rașșạ̄s's 
Kayfiyya, that is the latter's treatise on the Bahshamite theory of attributes, is recorded in manuscript form (Thiele 2013b). Al-Qāsim's main work in theology is, however, al-Ghurar wa-l-hujūl, an important supercommentary on Mānkdīm Shashdīw's (d. c.425/1034) Ta līq Sharh al-Ușūl al-khamsa. This text is a wealthy source on earlier Zaydī and non-Zaydī theologians and is in several respects fairly independent from the Ta' 'ìq. Al-Qāsim al-Muhallī takes greater interest in the topics of the preliminaries and the section on God's unity (tawhīd): both parts comprise more than the half of the whole text and consequently occupy a significantly larger portion than in Mānkdīm's work. In specific questions, al-Qāsim was apparently influenced by the teachings of al-Hasan al-Rașsāạ: he applies the same taxonomy to the 'effectors' (mu'aththirāt) and also follows al-Rașșāṣ's conceptual distinction between 'attributes' (șifät) and 'characteristics' (ahkēm) (Gimaret 1979: 63-5; al-Wajīh 1999: 765f.; Thiele 2013a: 75, 134).

Less than a century later, we see the rise of what might be called an encyclopedic attempt to canonize the teachings in theology and jurisprudence. Imam al-Mahdī li-Dīn Allāh Aḥmad b. Yahyyā al-Murtaḍā (d. 840/1436-7) wrote several works that became standard texts in Zaydī curricula and, in addition, attracted much attention from later commentators. His major work is al-Bahr al-zakhkhār al-jāmi 'li-madhāhib 'ulamā' al-anșār, a multi-volume encyclopedia of figh. The first introductory part of the work contains

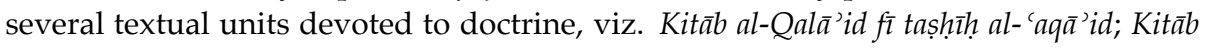
Riyādat al-afhām fī 'ilm al-kalām and $M i$ 'yār al-'uqūl fì 'ilm al-uṣul. These were later supplemented by Ibn al-Murtaḍā's own commentaries (al-Kamālī 1991: 105ff.; al-Wajīh 1999: 206-13 no. 199; van Ess 2011: ii. 986-95; Zysow 2012). Ibn al-Murtaḍā's doctrinal works are largely based on al-Hākim al-Jishumī's Kitāb 'Uyūn al-masā̄'il and his autocommentary, Sharh al- 'Uyūn, respectively. With regard to some subtle questions, Ibn al-Murtaḍa modifies al-Jishumī's positions according to the revisions suggested by al-Hasan al-Rașṣāṣ (Thiele 2011: 82f.; Schwarb 2015).

One of the most prolific theologians of the following generation was 'Ali $b$. Muhammad b. Aḥmad al-Bukurī (d. 882/1478) (al-Wajīh 1999: 709-10 no. 760; Schwarb 2015: passim). He authored a very popular commentary on al-Hasan al-Rașșāṣ's treatise on causation, which was read down to the eleventh/seventeenth century (Thiele 2011: 10f.). Numerous copies of the text with extensive glosses provide us with further details on the ongoing theological tradition of Bahshamite teaching in Yemen. They also reveal some details on treatises that were transmitted and read by scholars in theology: from these bits of texts, we can distil a list of quoted works by such theologians as al-Hasan al-Rașșās (namely his Kayfiyya), Humayd al-Muhallī (al-Kawākib al-durriyya), al-Qāsim b. Aḥmad al-Muhallī (al-Ghurar wa-l-ḥujūl), Ibn al-Murtaḍā (al-Bahrr al-zakhkhār), and, as the most important non-Zaydī authority, Ibn Mattawayh with many references to his Tadhkira.

\section{Counter-reactions}

While the theological trend of al-Hasan al-Rașșāṣ and his adherents continued to set the tone during the seventh/thirteenth century, growing opposition emerged among

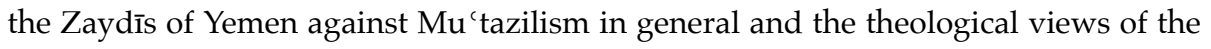


Bahshamiyya in particular. The most outspoken opponent of $\mathrm{Mu}^{\mathrm{c}}$ tazilite kalām was Nūr al-Dīn Abū 'Abd Allāh Ḥumaydān b. al-Qāsim b. Yahyā b. Humaydān (d. midseventh/thirteenth century), who sought to weaken its influence on Zaydī theology and to emphasize the latter's independence. For this purpose, he took recourse to the majāmī' literature of the earlier Imams (Madelung 1965: 218ff.; 'Abd al-Rahmān 2003b; Ansari 2012: 179-94; see also Section I). Moreover, the Zaydīs of Yemen were also introduced during this period to the teachings of Abū l-Husayn al-Bașrī, a former student of 'Abd al-Jabbār. Abū l-Husayn, who had also been trained in medicine and philosophy, had criticized the principles of the Bahshamiyya in an attempt to correct

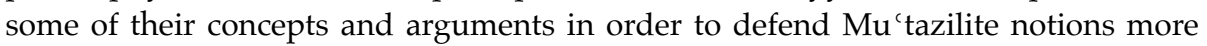
effectively against objections of their opponents. While there is no indication that Ja ' far b. Aḥmad had known any of Abū l-Husayn's works, his student Sulaymān b. Nāṣir al-Suhāmī (d. after 600 / 1203-4), who had also studied with Imam al-Mutawakkil 'alā llāh, wrote a Mukhtaṣar al-Mu'tamad, a summary of Abū l-Husayn al-Bașrī's Kitāb al$M u^{\prime}$ tamad fi $u s \underline{u}$ l al-figh on legal theory. ${ }^{8}$ The numerous manuscript copies of Yemeni provenance of Abū l-Husayn's Mu 'tamad also indicate that it was widely read among Zaydī scholars (Ansari and Schmidtke 2013a). This is not the case with Abū l-Husayn's theological works. Al-Ḥasan al-Rașșāṣ's student and follower of al-Manșūr bi-llāh, Abū l-Qāsim b. al-Husayn b. Shabīb at-Tihāmī (d. after 600/1203-4), is reported to have defended some specific views of Abū l-Husayn al-Bașrī against the Bahshamiyya (Madelung 1965: 222). There is no indication that Abū l-Husayn's most comprehensive kalām work, Tașaffuh al-adilla, ever reached Yemen. Yet, although no manuscript has surfaced so far of Abū l-Husayn's other important work, Kitäb Ghurar al-adilla, there is some indication that this text may have been accessible to Zaydi scholars in Yemen and Mecca. Ibn al-Walīd reports that al-Hasan al-Rașạaṣ wrote a refutation (radd) of the 'Kitāb al-Madkhal ilā Ghurar al-adilla li-l-Shaykh Abī l-Husayn al-Bașrī naqdan shāfiyan kāfiyan' which is not known to be extant. Since al-Rașșās was apparently concerned with the section of the imamate in particular, it is likely that 'Kitāb al-Madkhal ilā Ghurar al-adilla' was the title under which Abu 1-Husayn's Kitäb al-Ghurar (or perhaps only a section) was known among the Zaydīs of Yemen (Ansari 2010: 50). Moreover, the seventh/thirteenth-century Yemeni author 'Abd Allāh b. Zayd al-'Ansī quotes from the Ghurar in his al-Mahajja (Schmidtke 2013), and the above-mentioned Muhammad b. al-Hasan al-Daylamī explicitly refers to the Madkhal al-Ghurar on numerous occasions throughout his Qawā' $i d$ 'aqa') id Āl Muhammad.

The principal sources through which the Zaydīs of Yemen became acquainted with Abū l-Husayn's doctrines were the writings of Rukn al-Dīn Maḥmūd b. Muhammad alMalāhimīi al-Khwārazmī (d. 536/1141), and the Kitāb al-Kāmil fì uṣūl al-dīn by one Abū l-Ma 'ālī Șā 'id b. Aḥmad al- 'Ujālī al-Ușūūī—possibly a student of Ibn al-Malāhimìn. The latter was a contemporary and associate of Jār Allāh al-Zamakhsharī (d. 538/1144) and the chief representative of Abū 1-Husayn's thought a century after his death (Ansari and Schmidtke forthcoming b). Several partial copies of his al-Mu'tamad fì uṣūl al-

\footnotetext{
${ }^{8} \mathrm{Al}$-Suhāmīi also wrote Shams shar̄̄'at al-islām fì figh ahl al-bayt 'alayhim al-salām, containing two brief introductory sections on $u s ̦ \bar{u} l$ al-dīn and $u s ̦ \bar{u} l$ al-figh, while the majority of the work is devoted to figh. A manuscript of vol. i of this work, transcribed by 'Abd Allāh b. Hamza b. Muhammad b. Șabra al-Aslamī and dated Jumādā II 682/ August-September 1283, is preserved in the library of Muhammad b. Hasan b. Qāsim alHūthī. cf. al-Wajīh 1999: 470f.
} 
$d \bar{\imath} n$ are preserved in the libraries of Yemen, and the Maktabat al-awqāf of the Great

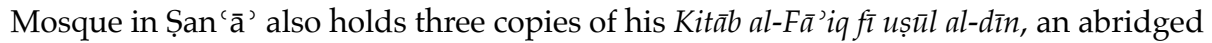
version of his $M u$ 'tamad, among them one copy that is dated 630/1232-3. There is documentary evidence that Ahmad b. Muhammad b. al-Hasan al-Raș̣̣ās al-Hafīd taught Ibn al-Malāhimīís Mu 'tamad, and his grandfather's student Sulaymān b. 'Abd Allāh al-Khurāshī regularly refers to and quotes from Ibn al-Malāhimimís $a l-F \bar{a}$ ' $i q$ and his alMu'tamad in his al-Tafșill li-jumal al-Tahṣill (Ansari and Thiele 2015). Al-Khurāshī's contemporary Ibn al-Walīd wrote (in Ramaḍān 608/February-March 1212) a refutation of the section on the imamate in Ibn al-Malāhimī's al-Fa' 'iq, entitled al-Jawāb al-nātiq alșādiq bi-hall shubah kitāb al-Fāa'iq (Ansari 2009). Ibn al-Malāhimī's Tuhfat al-mutakallimīn fi l-radd 'alā l-falāsifa was likewise known to Yemeni scholars of the sixth/twelfth century. Al-Hasan al-Rașsās wrote a refutation of the criticism that had been launched by Ibn al-Malāhimī against the philosophers' view that the existence (wujūd) of created beings is supplemental to their essence (māhiyya), al-Barāhīn al-zāhira al-jaliyya 'alā anna l-wujūd zā' id 'alā l-māhiyya, quoting extensively from Ibn al-Malāhimim's Tuhfa (Ansari 2007). The collection of the Maktabat al-awqāf of the Great Mosque in San ' $\bar{a}$ ' contains a manuscript of the Kitāb al-Kāmil by the above mentioned Șā 'id b. Aḥmad. This work systematically compares the teachings of the Bahshamiyya with those of Abu 1-Husayn al-Bașrī. The manuscript suggests that the Kitāb al-Kāmil was one of the earliest sources for the Zaydīs of Yemen for Abū l-Husayn al-Bașrī's doctrinal views. The colophon states that it was collated with a Vorlage transcribed from a copy of Sadid al-Dīn 'Amr b. Jamīl [Jumayl], a teacher of the Imam al-Manșūr bi-llāh. ${ }^{9}$ Muhammad b. Ibrāhīm Ibn al-Wazīr (d. 840/1436) also quotes extensively from the Kitāb al-Kāmil, although indirectly via the Kitāb al-Mujtabā fĩ ușūl al-dīn of the Khwārazmian Hanafī scholar Najm al-Dīn Mukhtār b. Maḥmūd al-Zāhidī al-Ghazmīnī (d. 658/1260) (Ansari and Schmidtke forthcoming $b$ ).

A leading figure of seventh/thirteenth-century Zaydī scholarship in Yemen was the mutakallim and legal scholar Husām al-Dīn Abū Muhammad 'Abd Allāh b. Zayd b. Aḥmad b. Abī l-Khayr al-'Ansī (b. 593/1196-7, d. Sha 'bān 667/April 1268), a prolific author in a variety of fields. According to the later biographical tradition, he has 105 titles to his credit (Ansari and Schmidtke, forthcoming a). To judge from the number of extant manuscripts, his most popular work was al-Irshād ilā najāt al- 'ibād, a work with Șūfī tendencies, which al- 'Ansī completed in Rabīi II 632/ January 1235. His mag-

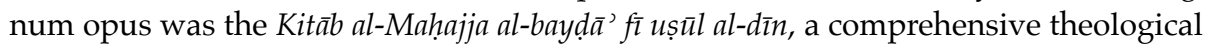

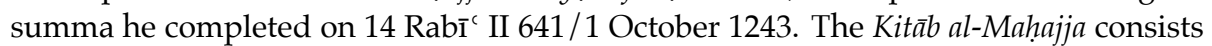
of eight parts (aqsām, sg. qism), a division that is characteristic for most of al- 'Ansī's theological works: (i) divine unicity (tawhīd); (ii) justice (' $a d l)$; (iii) prophecy (nubuwwa);

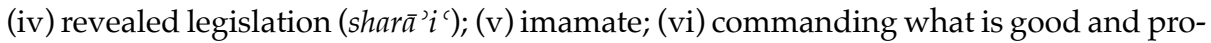
hibiting what is reprehensible (al-amr bi-l-ma'rüf wa-l-nahy 'an al-munkar); (vii) promise and threat ( $\left.a l-w a^{\prime} d w a-l-w a{ }^{(} \bar{\imath} d\right)$; (viii) attributes and characteristics (al-asmā' $w a-l-a h k \bar{a} m$ ).

\footnotetext{
${ }^{9}$ The work has been partly edited on the basis of a second copy of the text, MS Leiden OR 487, by E. Elshahed (al-Shahīd) (Elshahed 1983). Cf. the critical review by W. Madelung in Bulletin of the School of Oriental and African Studies 48 (1985) 128-9. Al-Shahīd has meanwhile published a full edition of the text ('Najrānī', Kāmil), again on the basis of the Leiden manuscript only. As is the case with Elshahed 1983, his introduction and edition is marred with glaring errors and misidentifications, including the author's nisba 'al-Najrānī'. See our Ansari and Schmidtke forthcoming b).
} 
Al-'Ansī was a severe critic of al-Hasan al-Rașṣāṣ and his followers in both doctrinal and political questions. As had been the case with Sayyid Humaydān, al- 'Ansī attempted to strengthen the influence of the doctrines of the earlier Imams, particularly those of al-Hādī, while reducing at the same time the influence of the Bahshamiyya. However, al-'Ansī did not share Humaydān's critical attitude towards Mu'tazilite kalām in general. Al- 'Ansī was familiar with a wide spectrum of $\mathrm{Mu}$ 'tazilite kalām literature: in addition to the theological writings of the earlier Imams al-Qāsim and al-Hādī, al-'Ansī was well acquainted with the theological literature of the Bahshamiyya and more specifically with texts written by students and companions of 'Abd al-Jabbār. He explicitly refers to the Kitāb al-Muhit to 'Abd al-Jabbār-no doubt referring to the paraphrastic commentary on the work by al-Hasan b. Ahmad Ibn Mattawayh, al-Majm $\bar{u}^{c}$ fì l-Muhīt bi-l-taklīf-and he regularly mentions the views of Abū Rashīd al-Nīsābūrī, Ibn Mattawayh, and al-Nāțiq bi-1-Haqq. Moreover, al- 'Ansī was also familiar with the theological writings of Ibn al-Malāhimī. Throughout the Mahajja, the views of Abū 1-Husayn and Ibn al-Malāhimī are regularly cited and discussed, and it seems that al- 'Ansī gleaned the relevant information primarily from Ibn al-Malāhimī's K. al$M u$ 'tamad. As mentioned above, al-'Ansī also quotes repeatedly from Abū l-Husayn alBașrī's K. Ghurar al-adilla throughout the Mahajja although it remains unclear whether or not he had the work at his disposal or was quoting from an intermediate source (Schmidtke 2013). In many respects, al-'Ansī preferred the views of Abū 1-Husayn and Ibn al-Malăhimī which, in his view, were often closer to the doctrines of the earlier Zaydī Imams than those of the Bahshamiyya and which he largely identified with those of the School of Baghdad. His approach towards their doctrinal thought is nevertheless critical, and al- 'Ansī follows their views only as long as they fit his overall agenda of formulating a theology that remains faithful to the teachings of the Imams (Ansari and Schmidtke forthcoming a: chapter 3).

At a later stage of his life, al-'Ansī composed the Kitāb al-Tamyīz, a refutation of the Mutarrifiyya which consists of three parts - a first introduction divided into the same eight fields of theology as the Mahajja: divine unicity, justice, prophecy and revealed laws, imamate, commanding what is good and prohibiting what is reprehensible, promise and threat, attributes and characteristics. For each domain, al- 'Ansī first presents the beliefs of the 'ahl al-islām', followed by those of the Mutarrifiyya which he then refutes. A second introduction, by far the most extensive portion of the text, contains a detailed refutation of the Muțarrifiyya arranged in eighty questions ( $m a$ ' $\bar{a} r i f$, sing. ma'rifa). The work is concluded by a khätima in which the author explains his own theological positions. This third section of the text constitutes a theological summa in its own right and has the same structure of eight parts (aqsām, sing. qism) as the Mahajja. The work represents an important cornerstone in the development of his thought: while the theological doctrine in the khätima of this work fully corresponds to what he maintained in his Mahajja, he now refrains from pointing out his agreement with either the Baghdādīs and/or Abū l-Husayn and Ibn al-Malāhimīì (these two are only mentioned at one single occasion throughout the entire khätima). Instead, he strongly and repeatedly insists on his agreement with the theological views of Imams al-Qāsim and al-Hādī, while his opposition against the Basran and, more specifically, Bahshamite doctrine remains outspoken in this work (Ansari and Schmidtke forthcoming a: chapters 3 and 5 no. 28, for an edition of the text, see chapter 6 Text 6). 
Al-'Ansī's doctrinal outlook also manifested itself in a conflict with the Banū Rașṣāṣ, particularly Aḥmad b. Muhammad al-Rașșāṣ al-Hafìd who, like his ancestors, was a staunch supporter of the Bahshamiyya. Apart from occasional critical remarks against al-Hasan al-Rașșās throughout the al-Mahajja, the later biographical tradition reports that al-'Ansī's conflict with the Hafid focused on the issue of whether or not the grave offender (fāsiq) holds an intermediary position (al-manzila bayn al-manzilatayn) between the believer and the unbeliever-while Ahmad al-Rașșāṣ supported the Mu'tazilite doctrine of the intermediary position, it was completely rejected by al- 'Ansi. While the relevant part of his Mahajja (the issue would have been addressed within Part Eight on al-asmā' wa-l-ahkām) is not preserved, al- 'Ansī discusses the issue in his brief tract $M \bar{a}^{\prime}$ al-yaqīn. Here, he states that the grave offender ( $\left.a l-f \bar{a} s i q\right)$ is an unbeliever by ingratitude ( $k \bar{a}$ fir al-ni'ma) (MS Glaser 123/3, ff. 235a-b; edition in Ansari and Schmidtke forthcoming a: Chapter 6 Text 3). Consequently, al-'Ansī opted for the traditional Zaydī doctrinal notion that had been favoured by al-Qāsim b. Ibrāhīm (Madelung 1965: 60ff., 121ff., 164ff.). According to Aḥmad b. Șāliḥ b. Muhammad b. Abī l-Rijāl (d. 1092/1690), the author of the bibliographical encyclopedia Mațlac al-budūr (Ibn Abī l-Rijāl, Mațla', i. 421; iii. 364 no. 957), the conflict gradually escalated. Al-' Ansī corresponded on the issue with 'Alī b. Yahyā al-Fuḍaylī and subsequently wrote a tract against the doctrine of the intermediate position. Ahmad al-Rașșās then intervened and composed a refutation of this tract, entitled Manāhij al-inșấf al- 'āṣima 'an shabb nār al-khilāf to which he later added a Muqaddimat al-manāhij. None of these writings has been preserved (Ansari and Schmidtke forthcoming a: Chapter 3).

Over the following generations, the tendency to prefer the doctrines of Abu 1-Husayn al-Bașrī and Ibn al-Malāhimī to those of the Bahshamiyya continued and even increased among the Zaydis of Yemen, and the conflict between the two groups seems to have become harsher. For example, al- 'Ansī's student Yahyā b. Manșūr b. al-'Afiff is specifically reported to have adopted the entire theological system of Abū 1-Husayn al-Bașrī (al-Shahārī, Ṭabaqāt, iii. 1263-4 no. 800). Moreover, Yahyā disputed and corresponded with some ' $u l a m \bar{a}$ ' al-zāhir' who followed the doctrines of Abū Hāshim with the specific aim to defend the views of the family of the Prophet (ahl al-bayt) and of Abū 1-Husayn (Ibn Abī l-Rijāl, Mațla', iv. 515). 'Alī b. al-Murtaḍā b. al-Mufaḍal (b. 704/1304-5, d. 784/1382-3) was another renowned adherent of the doctrines of Abū l-Husayn al-Bașrī who wrote a qașida in support of the latter. According to the later biographical tradition, he also corresponded and disputed with a number of scholars maintaining the views of Abū 1-Husayn and Ibn al-Malāhimī whereas his opponents are described as Bahshamites, as was the case with Ahmad b. Șalāḥ b. al-Hādī b. Ibrāhīm b. Tāj al-Dīn (Ibn Abī l-Rijāl, Mațla', iii. 351). 'Alī also disputed and subsequently corresponded with the jurist Ibrāhīm al-'Arārī (d. c.794/1391-2) (Ibn Abī l-Rijāl, Mațla', iii. 351; i. 159 no. 36; cf. also al-Waj̄̄h 1999: 722f. no. 778). The latter so staunchly supported the Bahshamiyya that he is reported to have stated that $A b \bar{u}$ ' $A l \overline{1}$ al-Jubbā' $\overline{1}$ and his son Abū Hāshim are preferable to Imams al-Qāsim and al-Hādī (Ibn Ab̄̄ l-Rijāl, Mațla', iii. 351). Word about this conflict spread and other scholars got involved writing refutations of Ibrāhīm al-'Arārī's unacceptable statement (Ibn Abī l-Rijāl, Mațla', iii. 352), namely Imam al-Mahdī 'Alī b. Muhammad b. 'Alī b. Manșūr b. al-Mufaḍdal (b. 705/1305-6, d. 773/1371-2) (al-Namraqa al-wusțā fì l-radd 'alā munkir āl al-muștafā), Imam al-Wāthiq bi-llāh (d. 
802 / 1400) (al-Naṣr al- 'azīz 'alā șāhib al-tajwwīz), and 'Alī b. al-Murtạ̣ā's sister, Șafīyat b. al-Murtaḍā (al-Jawāb al-wajīz 'alā șāhib al-tajwīz), all supporting the doctrinal views of Abū l-Husayn al-Bașrī. The evolution of the conflict between the two strands supports the assumption that the positive appreciation of the doctrinal views of Abū l-Husayn as against those of the School of Basra and, more specifically, the Bahshamiyya was founded mostly on their identification as being closer to, or perhaps even identical with, the traditional theology of the earlier Zaydī Imams (Ansari and Schmidtke forthcoming a: Chapter 4).

In this context, the case of Imam al-Mu'ayyad bi-llāh Yahyā b. Hamza al-Naqawī al-Mūsawī (b. 669/1270, d. 749/1348-9) rather seems to be an exception: in his encyclopedic Kitāb al-Shāmil fì uṣūl al-dīn (or: bi-haqā'iq al-adilla al- 'aqliyya wa-uṣūl al-masā'il al-diniyya), written in 711-12/1311-12, he adopted virtually the entire doctrinal system of Abū l-Husayn al-Bașrī. Moreover, he was the first to study in depth SunnīAsh 'arite works. Throughout his Shāmil, he regularly refers to Abū Hāmid al-Ghazālī (d. 505/1111) and Fakhr al-Dīn al-Rāzī (d. 606/1209)—for the latter, he explicitly cites from his Nihāyat al- 'uqūl fì dirāyat al-ușūl-whose positions he refutes. The popularity of his writings is indicated by the numerous extant manuscript copies as well as the fact that most of his theological works have been published (Schmidtke forthcoming).

Both traditions, the Bahshamite strand as well as the more conservative strand whose representatives sought to cling closely to the teachings of the Imams, continued over the centuries up until the modern period (Schwarb 2012).

\section{References}

'Abd al- 'Āțī, 'Abd al-Ghanī M. (2002). al-Șirā' al-fikrī fī l-Yaman bayna l-Zaydiyya wa-lMuțarrifiyya: Dirāsa wa-nuṣūṣ. al-Haram [Giza]: 'Ayn li-1-dirāsāt wa-1-buhūth al-insāniyya wa-l-ijtimā'iyya.

'Abd al-Raḥmān, M. (2003a). al-Imām Yahyā b. al-Husayn al-Rassī wa-ārā̄'uhu alkalāmiyya wa-l-falsafiyya. Alexandria: Dār al-Wafā’ li-dunyā l-țibā' 'a wa-l-nashr.

'Abd al-Raḥmān, M. (2003b). al-Imām Humaydān b. Humaydān wa-ārā'uhu al-kalāmiyya wa-l-falsafiyya. Alexandria: Dār al-Wafā' li-dunyā l-țibā'a wa-l-nashr.

Abrahamov, B. (1987). 'al-Ḳāsim ibn Ibrāhīm's Theory of the Imamate'. Arabica 34: 80-105.

Abrahamov, B. (1990). Al-Kāsim Ibn Ibrāhīm on the Proof of God's Existence: Kitāb al-Dalīl al-Kabīr. Leiden: Brill.

Abrahamov, B. (1996). Anthropomorphism and Interpretation of the Qur'ān in the Theology of al-Q̄assim ibn Ibrāhīm. Leiden: Brill.

Ahlwardt, W. (1887-99). Verzeichnis der arabischen Handschriften der Königlichen Bibliothek zu Berlin. 10 vols. Berlin: A. W. Schade [repr. Hildesheim: Olms, 1980-1].

Ansari, H. (2001). 'Yād-dāsht-i dar bāra-yi Muțarrifiyya wa raddī-hā-yi qāọī Ja 'far b. 'Abd al-Salām'. Kitāb-i māh-i dīn 49-50 (1380): 112-26.

Ansari, H. (2006). 'Falsafa-yi țab̄̄ '̄i-yi mu 'taziliyān-i muțarrifī’ . Kitāb-i māh-i dīn 102-3 (1385): 4-17.

Ansari, H. (2007). 'Al-Barāhīn al-ẓāhira al-jaliyya 'alā anna l-wujūd zā'id 'alā 1-māhiyya by Husām al-Dīn Abū Muḥammad al-Hasan b. Muhammad al- 
Raș̣āaș'. In C. Adang, S. Schmidtke, and D. Sklare (eds.), A Common Rationality: $M u$ 'tazilism in Islam and Judaism. Würzburg: Ergon, 337-48.

Ansari, H. (2009). 'Risāla-yi dar radd-i bar Maḥmūd b. al-Malāḥimī.' http:/ / ansari. kateban.com/ entry1573.html (accessed 12 May 2015).

Ansari, H. (2010). 'Maḥmūd al-Malāḥimī l-Mu 'tazilī fī Yaman wa-ta 'rīf bi-risāla fī lradd 'alayhi hawla ziyādat al-wujūd 'alā l-māhiyya'. al-Masār 11/2: 48-58.

Ansari, H. (2011). 'Ahmmad b. 'İsā b. Zayd'. Encyclopaedia Islamica, Leiden: Brill, iii. $249-52$.

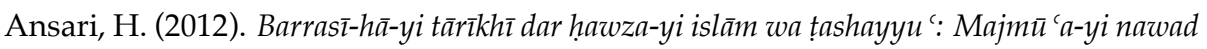
maqāla wa yaddāsht. Tehran, Kitābkhāna, mūze wa markaz-i asnād-i majlis-i shūrā-yi islāmīi, 1390.

Ansari, H. (2013). 'Dū jild-i tāze yābe sīra-yi Manșūr bi-llāh'. http:/ / ansari.kateban. com/ entry2096.html (accessed 13 May 2015).

Ansari, H., and S. Schmidtke (2010). 'Mu'tazilism after 'Abd al-Jabbār: Abū Rashīd al-Nīsābūrī's Kitāb Masā'il al-khilāff fí l-uṣūl'. Studia Iranica 39: 225-77.

Ansari, H., and S. Schmidtke (2011). 'The Literary-Religious Tradition among 7th / 13th Century Yemeni Zaydīs: The Formation of the Imām al-Mahdī li-Dīn Allāh Aḥmad b. al-Husayn b. al-Qāsim (d. 656/1258'). Journal of Islamic Manuscripts 2: $165-222$.

Ansari, H., and S. Schmidtke (2013a). 'The Mu'tazilī and Zaydī Reception of Abū 1Husayn al-Bașrī's Kitāb al-Mu 'tamad fì ușūl al-fiqh: A Bibliographical Note'. Islamic Law and Society 20: 90-109.

Ansari, H., and S. Schmidtke (2013b). 'Between Aleppo and Șa 'da: The Zaydī Reception of the Imāmī Scholar Ibn al-Bițrīq al-Hillī̄'. Journal of Islamic Manuscripts 4: 160-200.

Ansari, H., and S. Schmidtke (forthcoming a). Zaydī Mu'tazilism in 7th/13th Century Yemen: The Theological Thought of 'Abd Alläh b. Zayd al-'Ansī (d. 667/1268).

Ansari, H., and S. Schmidtke (forthcoming b). The Transmission of Abu l-Husayn al-Bașrī's (d. 436/1044) Thought and Writings.

Ansari, H., and J. Thiele (2015). 'MS Berlin, State Library, Glaser 51: A Unique Manuscript from the Early 7th/13th-Century Bahšamite Milieu in Yemen'. In D. Hollenberg, C. Rauch, and S. Schmidtke (eds.), The Yemeni Manuscript Tradition. Leiden: Brill, 66-81.

Elshahed, E. (1983). Das Problem der transzendenten sinnlichen Wahrnehmung in der spätmu'tazilitischen Erkenntnistheorie nach der Darstellung des Taqiaddin an-Nă̆rān̄̄. Berlin: Klaus Schwarz.

van Ess, J. (2011). Der Eine und das Andere: Beobachtungen an islamischen häresiographischen Texten. 2 vols, Berlin: de Gruyter.

Gimaret, D. (1979). 'Les Ușūl al-hnamsa du Qāḍī 'Abd al-Ǧabbār et leurs commentaires'. Annales Islamologiques 15: 47-96.

al-Hādī ilā l-ḥaqq, Yahyāa b. al-Husayn (Majmū'). Majmū' rasā’il al-Imām al-Hādī ilā lHaqq: al-Rasā'il al-uṣūliyya. Ed. 'Abd Allāh b. Muhammad al-Shādhilī. Amman: Mu'assasat al-Imām Zayd b. 'Alī al-thaqāfiyya, 2001.

al-Hādī ilā l-ḥaqq, Yahyā b. al-Husayn (Majmū'a fäkhira). Al-Majmū'a al-fäkhira: Kitāb fïhi majmī ‘ min kutub al-Imām al-Hād̄ ... Ed. 'Alī Aḥmad Muḥammad al-Rāziḥī. Sanaa: Dār al-hikma al-yamaniyya, 1420/ 2000. 
al-Ḥusayn b. Badr al-Dīn Muhammad. Yanābī' al-nașịha fi l-'aqā'id al-ṣah̄ihha. Ed. alMurtạ̣ā b. Zayd al-Maḥațwarī al-Hasanī. Sanaa: Maktabat Badr, 1422 / 2001.

al-Husayn b. al-Qāsim al-'Iyānī (Majmū'). Min majmū' kutub wa-rasā̄'il al-Imām al'Iyānī. Sanaa: Markaz al-turāth wa-l-buhūth al-yaman̄i, 2006.

Ibn Abī l-Rijāl Aḥmad b. Șāliḥ (Mațla'). Maṭla' al-budūr wa-majma' al-buḥūr fĩ tarājim rijāl al-zaydiyya 1-4. Ed. Majd al-Dīn b. Muhammad b. Manșūr al-Mu’ayyidī. Șa 'da: Markaz ahl al-bayt li-l-dirāsāt al-islāmiyya, 2004.

Ibn Di'tham, Abū Firās (Sīra). al-Sīra al-sharīfa al-Manșūriyya: Sīrat al-Imām 'Abd Allāh b. Hamza, 593-614. Ed. 'Abd al-Ghanī Maḥmūd 'Abd al- 'Āṭ̂̄. Beirut: Dār al-fikr al-mu'āșir, 1414/1993.

Jarrar, M. (2012). 'Al-Manșūr bi-Llāh's Controversy with Twelver Š̄î̀ites Concerning the Occultation of the Imam in his Kitāb al- 'Iqd al-tamīn'. Arabica 59: 319-31.

Jundārī, A. (Tarājim). 'Tarāijm al-rijāl al-madhkūra fī Sharḥ al-Aẓhār'. Published in the introduction to 'Abd Allāh b. Abī l-Qāsim Ibn Miftāh, al-Muntaza' al-mukhtār min al-Ghayth al-midrār al-ma' 'rüfbi-Sharh al-Aẓhār. Sanaa, 1341/1922-3.

al-Kamālī, M. M. al-Hāijj H. (1991). al-Imām al-Mahd̄̄ Ahmad b. Yahyāa al-Murtad̄̄a wa-atharuhu fì l-fikr al-islāmī siyāsiyan wa-'aqā'idiyyan. Sanaa: Dār al-ḥikma al-yamaniyya, 1411.

al-Khurāshī, Sulaymān b. 'Abd Allāh (Tafṣ̂ll). Kitāb al-Tafṣ̄il li-ğumal al-Tahṣ̂̄l. Facsimile edn. of MS Berlin, Glaser no. 51. With Introductions and Indexes by H. Ansari and J. Thiele. Tehran: Mīrāth-i maktūb, 2013.

Lane, A. J. (2006). A Traditional Mu'tazilite Qur'ān Commentary: The Kashshāf of Jār Allāh al-Zamakhsharī (d. 538/1144). Leiden: Brill.

Levi Della Vida, G. (1935). Elenco dei manoscritti arabi islamici della Biblioteca vaticana: Vaticani, Barberiniani, Borgiani, Rossiani. Vatican: Biblioteca apostolica vaticana.

Madelung, W. (1965). Der Imam al-Qāsim ibn Ibrāhīm und die Glaubenslehre der Zaiditen. Berlin: de Gruyter.

Madelung, W. (1975). 'A Muțarrifī Manuscript'. In Proceedings of the VIth Congress of Arabic and Islamic Studies. Stockholm: Almqvist \& Wiksell, 75-83.

Madelung, W. (1977). 'The Sīrat al-Amīrayn al-Ajallayn al-Sharīfayn al-Fāẹilayn alQāsim wa-Muhammad ibnay Ja'far ibn al-Imām al-Qāsim b. 'Alī al-'Iyānī as a Historical Source'. In Studies in the History of Arabia, I: Sources for the History of Arabia, part 2. Proceedings of the First International Symposium on Studies in the History of Arabia. Riyad, April 1977. Riyad: University of Riyadh Press, 69-87.

Madelung, W. (1980). 'Abū 1-Fath al-Daylamī'. The Encyclopaedia of Islam. New edn. Leiden: Brill, Supplement, 22.

Madelung, W. (ed.) (1985). Streitschrift des Zaiditenimams Ahmad an-Nāṣir wider die ibaditische Prädestinationslehre. Wiesbaden: Steiner.

Madelung, W. (1989). 'Imam al-Qāsim ibn Ibrāhīm and Mu'tazilism'. In U. Ehrensvärd and C. Toll (eds.), On Both Sides of al-Mandab: Ethiopian, South-Arabic and Islamic Studies Presented to Oscar Löfgren. Stockholm: Svenska Forskningsinstitutet i Istanbul, 39-47.

Madelung, W. (ed.) (1990). The Sīra of Imām Aḥmad b. Yahyā Al-Nāṣir li-Dīn Allāh from Musallam al-Lahjī's Kitāb Akhbār Al-Zaydiyya bi 1-Yaman. Exeter: Ithaca Press.

Madelung, W. (1991a). 'The Origins of the Yemenite Hijra'. In Arabicus felix luminosus britannicus: Essays in Honour of A. F. L. Beeston on his Eightieth Birthday. Reading: 
Ithaca Press, 25-44.

Madelung, W. (1991b). 'Al-Qāsim ibn Ibrāhīm and Christian Theology'. Aram 3: 35-44.

Madelung, W. (2002). 'Zayd b. 'Alī b. al-Husayn'. The Encyclopaedia of Islam. New edn. Leiden: Brill 11/473f.

al-Manșūr bi-llāh 'Abd Allāh b. Hamza (Sharh). Sharh al-Risāla al-nāṣiha bi-l-adilla alwāẹiha. Ed. Ibrāhīm Yahyā al-Darsī al-Hamzī and Hādī b. Hasan b. Hādī alHamzī. Șa 'da: Markaz ahl al-bayt ( c ) li-l-dirāsāt al-islāmiyya, 1423/2002.

al-Manșūr bi-llāh 'Abd Allāh b. Hamza ('Iqd). al- Iqd al-thamīn fì ahkē̄m al-a'imma alhādīn. Ed. 'Abd al-Salām b. 'Abbās al-Wajīh. McLean, VA: Mu'assasat al-Imām Zayd b. 'Alī al-thaqāfiyya, 1421/2001.

al-Manșūr bi-llāh 'Abd Allāh b. Hamza (Majmū'). Majmū' rasā’il al-Imām al-Manșūr billāh 'Abd Allāh b. Hamza. Ed. 'Abd al-Salām b. 'Abbās al-Wajīh. 2 vols. McLean, VA: Mu'assasat al-Imām Zayd b. 'Alī al-thaqāfiyya, 1422/2002.

Mohaqqeq, S. (2008). 'Abū l-Fath al-Daylamī'. Encyclopaedia Islamica, Leiden: Brill, i. 756-8.

Muhammad b. al-Qāsim al-Rassī (Majmū' '). Majmū' kutub wa-rasā’’il al-Imām Muhammad b. al-Q̄̄sim al-Rassī. Ed. 'Abd al-Karīm Aḥmad Jadbān. Șa'da: Maktabat al-turāth al-islāmī, 1423/2002.

al-Murtaḍā li-Dīn Allāh Muhammad b. Yahyyā al-Hādī (Majmū'c). Majmū' kutub warasā' il al-Imām al-Murtad̄a Muhammad b. Yahyā al-Hādì. 2 vols. Șa 'da: Maktabat al-turāth al-islāmī, 1423/2002.

al-Mutawakkil 'alā llāh, Aḥmad b. Sulaymān (Haqā'iq). Haqā'iq al-ma'rifa fì 'ilm alkalām. Ed. Hasan b. Yahyā al-Yūsufī. Sanaa: Mu'assasat al-Imām Zayd b. 'Alī al-thaqāfiyya, 1424/2003.

'al-Najrān̄̄, Taqī al-Dīn' (Kāmil). Al-Kāmil fī l-istiqșā̄' fìmā balaghanā min kalām al-qudamā'. Ed. al-Sayyid al-Shahīd. Cairo: Wizārat al-awqāf, 1999.

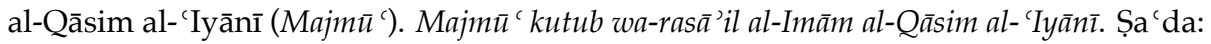
Maktabat al-turāth al-islāmī, 2002.

al-Raba ' $\overline{1}$, Mufarriḥ b. Aḥmad (Sīra). Sīrat al-amīrayn al-jalīlayn al-sharīfayn al-fādilayn

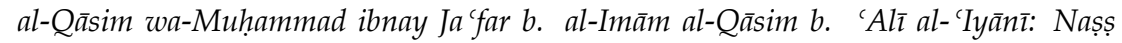
tārīkh̄̄ Yaman̄̄ min al-qarn al-khāmis al-Hijrī. Ed. R. al-Sayyid and 'Abd al-Ghanī M. 'Abd al-' 'Āṭi. Beirut: Dār al-muntakhab al- 'arabī, 1413/1993.

Schmidtke, S. (1991). The Theology of al-'Allāma al-Hillī (d. 726/1325). Berlin: Klaus Schwarz.

Schmidtke, S. (2013). 'Biblical Predictions of the Prophet Muhammad Among the Zaydīs of Yemen (6th/12th and 7th/13th Centuries)'. Orientalia Christiana Analecta 293: 221-40.

Schmidtke, S. (forthcoming). 'Imām al-Mu'ayyad bi-llāh Yahya b. Hamza (b. 669/1270, d. 749/1348-9) and his K. al-Shāmil li-haqā'iq al-adilla al-'aqliyya wa-ușūl al-masā' il al-dīniyya'.

Schwarb, G. (2011). 'Mu'tazilism in the Age of Averroes'. In P. Adamson (ed.), In the Age of Averroes: Arabic Philosophy in the Sixth/Twelfth Century. London: The Warburg Institute, 251-82.

Schwarb, G. (2012). 'Mu'tazilism in a 20th Century Zaydī Qur'ān Commentary'. Arabica 59: 371-402. 
Schwarb, G. (2015). 'MS Munich, Bavarian State Library, Cod. arab. 1294: A Guide to Zayd̄̄ Kalām-Studies During the Țāhirid and Early Qāsimī Periods (Mid-15thEarly 18th Centuries)'. In D. Hollenberg, C. Rauch, and S. Schmidtke (eds.), The Yemeni Manuscript Tradition. Leiden: Brill, 155-202.

al-Shahārī, Ibrāhīm b. al-Qāsim (Țabaqāt). TTabaqāt al-zaydiyya al-kubrā (al-qism al-thālith) wa-yusammā Bulūgh al-murād ilā ma'rifat al-isnād. Ed. 'Abd al-Salām b. 'Abbās al-Wajīh. 3 vols. McLean, VA: Mu'assasat al-Imām Zayd b. 'Al̄̄ al-thaqāfiyya, $1421 / 2001$

Sobieroj, F. (2007). Arabische Handschriften der bayerischen Staatsbibliothek zu München unter Einschluss einiger türkischer und persischer Handschriften. Vol. i. Stuttgart: Steiner.

al-Thaqafī, Sulaymān b. Yaḥyā (Sīra). Sirat al-Imām Ahmad b. Sulaymān 532-566 H. Ed. 'Abd al-Ghanī Maḥmūd 'Abd al-' Âțī. Giza: 'Ayn li-l-dirāsāt wa-l-buhūth alinsāniyya wa-l-ijtimā iyya, 2002.

Thiele, J. (2010). 'Propagating Mu'tazilism in the VIth/XIIth Century Zaydiyya: The Role of al-Hasan al-Rașșāṣ'. Arabica 57: 536-58.

Thiele, J. (2011). Kausalität in der mu 'tazilitischen Kosmologie: Das Kitāb al-Mu'attirāt wamiftāḥ al-muškilāt des Zayditen al-Hasan ar-Rașșāṣ (st. 584/1188). Leiden: Brill.

Thiele, J. (2012). 'La Causalité selon al-Hākim al-Ǧišumī'. Arabica 59: 291-318.

Thiele, J. (2013a). Theologie in der jemenitischen Zaydiyya: Die naturphilosophischen Überlegungen des al-Hasan ar-Rașșāṣ. Leiden: Brill.

Thiele, J. (2013b). 'A propos de l'attribution du ms Ambrosiana ar. F 122, fol. 35b: un fragment d'un texte zaydite du Yémen'. Chroniques du manuscrit au Yémen 16: 16-24.

Thiele, J. (in press). 'Theological Compendia in Late 6th/12th and Early 7th/13th Century Zaydism: al-Hassan al-Rașṣāṣ's K. al-Taḥṣ̂ll and its Commentaries'. In L. Mühlethaler, S. Schmidtke, and G. Schwarb (eds.), Theological Rationalism in the Medieval World of Islam: New Texts and Perspectives. Leuven: Peeters.

al-Wajīh, 'Abd al-Salām b. 'Abbās (1999). A 'lām al-mu'allifīn al-Zaydiyya. McLean, VA: Mu' assasat al-Imām Zayd b. 'Alī al-thaqāfiyya.

Zaryāb, 'A. (1994). 'Abū 1-Qāsim Balkhī'. Dā'irat al-ma' 'ārif-i buzurg-i islāmī 6: 150-7.

Zayd, 'A. M. (1997). Tayyārāt Mu'tazilat al-Yaman fì l-Qarn al-Sādis al-Hijrī. Sanaa: alMarkaz al-faransī li-1-dirāsāt al-yamaniyya.

Zayd b. 'Alī b. al-Husayn (Majmū'). Majmū' kutub wa-rasā'il al-Imām al-a zam Amīr al-mu'min̄̄n Zayd b. 'Alī b. al-Husayn b. 'Alī b. Abī Țālib. Ed. Ibrāhīm YahyāalDarsī al-Hamzī. Șa ‘da: Markaz Ahl al-bayt li-l-dirāsāt al-islāmiyya, 1422/2001.

Zysow, A. (2012). 'Kalām Works by Ibn al-Murtaḍā'. Unpublished paper delivered at the occasion of the International Workshop 'The Yemeni Manuscript Digitization Initiative (YMDI)'. Staatsbibliothek zu Berlin, 9-10 May 2012. 